\title{
PIK3CG Gene Mutation
}

National Cancer Institute

\section{Source}

National Cancer Institute. PIK3CG Gene Mutation. NCI Thesaurus. Code C146727.

A change in the nucleotide sequence of the PIK3CG gene. 